\title{
PENGARUH PERSEPSI SISWA TENTANG KETERAMPILAN MENGAJAR GURU, FASLISITAS BELAJAR, PERGATIAN ORANG TUA, LINGKUNGAN SEKOLAH DAN MOTIVASI BELAJAR TERHADAP EFEKTIVITAS BELAJAR SISWA MATA PELAJARAN EKONOMI KELAS XI DI SMAN 3 SOLOK SELATAN
}

\author{
Wedi Irwan, Desi Areva, Stevani \\ Program Studi Pendidikan Ekonomi STKIP PGRI Sumatera Barat \\ wediirwan9319@gmail.com
}

\begin{abstract}
This study aims to analyze, 1) the partial efekct of teacher teaching skills on student learning motivation, 2) the effect of learning facilities on student learning motivation, 3) the effect of parental attention on student learning motivation, 4) the influence of the school environment on student learning motivatin, 5) the effect of partially teaching teacher skills on the effectiveness of student learning, 6) the effect of learning facilities partially on the effectiveness of student learning, 7) the effect of parental attention partially on the effectiveness of student learning. 8) partially influencing the school environment on the effectiveness of student learning, 9) partially influencing learning motivation on the effectiveness of student learning. The results showed that (1) the variable teacher skills obtained a coefficient of tcount of 4.932> t Table (1.993) (2) the learning facilities variable obtained a coefficient of tcount of 4.519> $\mathrm{t}$ Table (1.99) (3) the variable parental attention obtained a coefficient value $t$ count of 2.132> $t$ Table (1.993) (4) The school environment variable obtained the $t$ count coefficient of -5.490> tTable (1.993) (5) the teaching teacher skill variable obtained the t count coefficient of 1.931>t Table (1.993) (6) the learning facilities variable obtained $t$ count coefficient value of $-2,804>t$ Table $(1,993),(7)$ variable parental attention obtained $t$ count coefficient value of 2,675> $t$ Table $(1,993),(8)$ school environment variable obtained t count coefficient value of 2,056> $\mathrm{t}$ Table (1,993), (9) the learning motivation variable obtained $\mathrm{t}$ count coefficient of 3,350>t Table $(1,993)$.
\end{abstract}

Keywords: Teacher Skills in Teaching, Learning Facilities, Parents' Attention, School Environment, Learning Motivation, and Student Learning Effectiveness.

PENDAHULUAN

Dalam perkembangan zaman, pendidikan memiliki peran yang sangat penting dalam meningkatkan kemajuan pribadi seseorang, kemajuan suatu daerah bahkan negara sehingga 
dibutuhkan langkah-langkah tertentu untuk dapat meningkatkan mutu pendidikan. Efektivitas pada umumnya menyangkut satu atau letak harapan yang ingin dicapai dalam suatu kegiatan sedangkan efektivitas pembelajaran adalah suatu kegiatan tergantung terlaksana atau tidak perencanaan yang telah ditargetkan secara khusus dalam konteks pengajaran disekolah, sasaran yang yang dimaksud dapat ditunjukan melalui sejumlah indikator. misalnya Tabel 1. Nilai Rata-rata UN, Akreditasi Sekolah, Jumlah Guru Sertifikasi SMA Negeri di Solok Selatan.

\begin{tabular}{|c|c|c|c|c|c|c|c|}
\hline \multirow[t]{2}{*}{ No } & \multirow[t]{2}{*}{ Nama Sekolah } & \multirow[t]{2}{*}{ Akreditasi } & \multicolumn{3}{|c|}{ Rata-rata Nilai UN } & \multicolumn{2}{|c|}{$\begin{array}{l}\text { Jumlah } \\
\text { Sertifikasi }\end{array}$} \\
\hline & & & 2017 & 2018 & 2019 & $\begin{array}{l}\text { Guru } \\
\text { Sertifi } \\
\text { kasi }\end{array}$ & $\begin{array}{l}\text { Guru Non } \\
\text { Sertifikasi }\end{array}$ \\
\hline 1 & $\begin{array}{l}\text { SMAN } 2 \text { Solok } \\
\text { Selatan }\end{array}$ & B & 60,78 & 58,76 & 58,51 & 16 & 12 \\
\hline 2 & $\begin{array}{l}\text { SMAN } 3 \text { Solok } \\
\text { Selatan }\end{array}$ & B & 48,62 & 44,34 & 51,78 & 29 & 35 \\
\hline 3 & $\begin{array}{l}\text { SMAN } 4 \text { Solok } \\
\text { Selatan }\end{array}$ & B & 54,30 & 55,02 & 55,63 & 30 & 13 \\
\hline 4 & $\begin{array}{l}\text { SMAN } 6 \text { Solok } \\
\text { Selatan }\end{array}$ & B & 47,61 & 49,70 & 51,79 & 21 & 12 \\
\hline 5 & $\begin{array}{l}\text { SMAN } 7 \text { Solok } \\
\text { Selatan }\end{array}$ & B & 48,70 & 48,62 & 49,36 & 19 & 9 \\
\hline & Rata-rata Nilai U & & 52,00 & 51,28 & 53,41 & & \\
\hline
\end{tabular}

Sumber: Referensi Data Kemendikbutd

Dalam keefektivitas belajar setiap siswa dituntut untuk belajar dengan maksimal sesuai dengan yang penguasaan siswa serta hasil akademik lainnya setelah proses pelajaran selesai sesuai dengan yang di targetkan atau di rencanakan oleh guru. Dapat di lihat dari tabel dibawah ini rata-rata nilai Ujian Nasional dan dapat juga di lihat dari Akreditasi sekolah atau Jumlah Guru Sertifikasi SMA Negeri di Solok Selatan.

Arikunto (2004:51) Efektivitas adalah taraf tercapainya suatu tujuan yang telah ditentukan. 
Faktor pertama yang mempengaruhi keefektifan belajar yaitu bagaimana siswa memandang keterampilan mengajar di kelas. Berdasarkan Slameto. (2003:102), persepsi iyalah proses dimana pesan atau informasi dimasukkan pada otak manusia.

Faktor kedua rang
mempengaruhi efektivitas belajar
adalah fasilitas belajar. Menurut Sani.
$(2013: 48)$, proses belajar mengajar
akan berlangsung efektif jika didukung
oleh institusi yang sesuai.

Faktor ketiga yang mempengaruhi efektivitas belajar adalah perhatian orang tua. Berdasarkan Nashori, (2005;51), kalau perhatian orangtua kepada anak iyalah menemaninya ataupun mendampinginya pada waktu belajar, memberikan arahan, pemberitahuan serta juga mengawasi pada saat anaknya beraktivitas, memberikan semangat, hadiah, menjadi teladan untuk anaknya, serta memberikan hak yang sama kepada semua anaknya tampa membeda-bedakannya.
Faktor keempat yang mempengaruhi keefektifan pembelajaran adalah lingkungan sekolah. Berdasarkan Tu'u. (2004:1), lingkungan sekolah adalah sebagai lembaga pendidikan formal tempat berlangsungnya proses belajar mengajar, ilmu pengetahuan disebarluaskan kepada siswa.

Faktor kelima yang mempengaruhi efektivitas belajar adalah motivasi belajar. Berdasarkan Sardiman (2011:73), motivasi merupakan upaya mendorong seseorang untuk melakukan sesuatu yang disebut dengan motif. Ini mendorong orang untuk bertindak atau bertindak dan bertindak sebagai penggerak atau mesin yang member seseorang energy atau kekuatan untuk melakukan sesuatu.

Menurut latar belakang diatas, dapat peneliti ambil untuk melakukan penelitian mengenai "Pengaruh $\begin{array}{lll}\text { Persepsi } & \text { Siswa } & \text { Tentang }\end{array}$ Keterampilan Mengajar Guru, Fasilitas Belajar, Perhatian Orang Tua, Lingkungan Sekolah dan Motivasi Belajar Terhadap 
Efektivitas Belajar Siswa pada Mata

Pelajaran Ekonomi kelas XI IPS di

SMA Negeri 3 Solok Selatan”.

\section{METODE PENELITIAN}

Penelitian ini iyalah Asosiatif.

Berdasarkan Arikunto. (2006:239), metode asosiatif iyalah penyelidikan yang bertujuan untuk menemukan ada atau tidaknya hubungan dan apa hubungannya. Penelitian ini dilakukan pada SMAN 3 Solok Selatan Penelitian inidilakukan di SMAN 3 Solok Selatan Jln. Lubuk Gadang, kec. Sangir kab. Solok Selatan. Provinsi Sumbar. Teknik pengambilan sampel sebanyak 75 siswa diambil secara stratified random sampling (sampel berstrata), cara mengumpulkan data yaitu angket dan observasi. Penulis melakukan uji coba kepada 30 orang murid kelas XI IPS SMAN 6 Solok Selatan karena memiliki Akreditasi sekolah yang sama yaitu B dan mata pelajaran ekonomi menetapkan Kriteria Ketuntasan Minimum yaitu 78. Analisis data iyalah cara untuk mengolah data yang telah di kumpulkan kemudian dapat memberikan interprestasi. Hasil pengolahan ini dapat digunakan untuk menjawab rumusan masalah.

\section{HASIL DAN PEMBAHASAN}

Berdasarkan TCR masingmasing variabel diperoleh rerata variabel keefektifan belajar sebesar 4,13\% dengan TCR responden $82,52 \%$. Ini melihatkan kalau keefektifan pembelajaran dalam kategori baik. Variabel mean keterampilan guru mengajar di kelas adalah 3,76\%, dengan TCR responden $75,11 \%$. Hal ini menunjukkan bahwa keterampilan guru mengajar di kelas berada pada kategori cukup.

Variabel rata-rata lembaga pembelajaran sebesar $4,48 \%$ dengan TCR responden 89,59\%. Ini melihatkan kalau institusi pendidikan dalam keadaan baik. Variabel rerata perhatian orangtua adalah $4,11 \%$ dengan tingkat kinerja responden (TCR) sebesar 82,27\%. Hal tersebut melihatkan kalau X4 dalam keadaan baik.

Variabel rerata untuk lingkungan sekolah adalah 4,46\% 
dengan tingkat kinerja responden (TCR) $89,13 \%$. Ini melihatkan kalau lingkungan sekolah dalam keadaan baik dan variabel rerata motivasi belajar adalah 4,06\%, pada tingkat prestasi responden (TCR) 81,29\%. Ini melihatkan kalau motivasi belajar dalam keadaan baik.

Setelah dilakukannya analisa deskriptif, dilakukan analisa inferensial untuk melihat pengaruh langsung atau tidaknya persepsi siswa terhadap kemampuan guru dikelas, fasilitas belajar, perhatian orangtua, lingkungan sekolah dan motivasi belajar terhadap keefektifan belajar Tabel 2. Hasil Analisis Jalur Sub Struktur I

\begin{tabular}{lcccc}
\hline \multicolumn{1}{c}{ Variabel Bebas } & $\begin{array}{c}\text { Koefisien } \\
\text { Jalur }\end{array}$ & $\mathrm{T}$ & $\mathrm{Sig}$ & Ket \\
\hline keterampilan guru mengajar (X1) & 0,161 & 1,931 & 0,058 & Signifikan \\
fasilitas belajar (X2) & $-0,573$ & $-2,804$ & 0,007 & Signifikan \\
perhatian orang tua (X3) & 0,354 & 2,675 & 0,009 & Signifikan \\
Lingkungan sekolah (X4) & 0,142 & 2.056 & 0,043 & Siginfikan \\
\hline
\end{tabular}

F hitung : 6,116

F sig : : 0,000

R square : 0,259

Sumber: Olahan Data Primer (Peneliti) SPSS, 2020

Berdasarkan analisis pengaruh variabel keterampilan guru mengajar $\left(\mathrm{X}_{1}\right)$ terhadap variabel motivasi belajar $\left(\mathrm{X}_{5}\right)$ melihatkan koefisien jalur $\rho_{\mathrm{X} 5 \mathrm{X} 1}=$ 0,161 . Poin $t$ hitung $=1,931$ dengan siswa pada mata pelajaran ekonomi kelas XI yang akan dilakukan di SMAN 3 Solok Selatan.

Hasil uji normalitas diraih poin statistik Jarque-Bera sebesar 29,03 sedangkan poin $\mathrm{X}^{2 \text { tabel }}$ dengan poin $\mathrm{df}$ : 0,05 iyalah 96,217. Sebab poin statistik Jeque-Bera (JB) $(29,01)<$ poin $\mathrm{X}^{2}$ tabel $(96,217)$. Demikian dapat dilihat kalau poin residual berdistribusi normal.

Tahap pengujian analisis jalur dibagi menjadi 2 yaitu substruktur 1 dan substruktur 2, untuk melakukan analisis jalur. Aplikasi SPSS versi 16.0 dipakai dalam penelitian ini. 
bahwa apabila keterampilan guru mengajar meningkat maka motivasi belajar akan meningkat juga.

Pengaruh variabel fasilitas belajar $\left(\mathrm{X}_{2}\right)$ terhadap variabel motivasi belajar $\left(\mathrm{X}_{5}\right)$ melihatkan koefisien jalur $\rho_{\mathrm{X} 5 \mathrm{X} 2}=-0,573$. Poin $t$ hitung $-2,804$ sama poin sig $0,007<0,05$ melihatkan kalau lembaga pembelajaran mempunyai dampak negatif yang signifikan kepada motivasi belajarnya. Ini memberikan gambaran bahwa apabila fasilitas belajar meningkat maka motivasi belajar akan mengalami penurunan tergantung fungsinya.

Pengaruh perhatian orangtua (X3) kepada motivasi belajar $\left(\mathrm{X}_{5}\right)$ menunjukkan koefisien jalur $\rho_{\mathrm{X} 5 \mathrm{X} 3}=$ 0,354 . Poin $t$ hitung iyalah 2,675 dengan poin sig $0,009<0,05$ menunjukkan kalau perhatian orangtua berdampak positif signifikan terhadap motivasi belajar. Hal ini melihatkan kalau semakin besar perhatian orangtua maka semakin besar pula motivasi belajarnya.

Pengaruh variabel lingkungan sekolah $\left(\mathrm{X}_{4}\right)$ terhadap variabel motivasi belajar $\left(\mathrm{X}_{5}\right)$ menunjukkan koefisien jalur $\rho_{\mathrm{X} 5 \mathrm{X} 4}=0,293$. Poin $\mathrm{t}$ hitung iyalah 2,056 dengan taraf sig $0,043<0,05$ melihatkan kalau lingkungan sekolah mempunyai dampak positif yang signifikan kepada motivasi belajarnya. Ini memberikan gambaran bahwa apabila lingkungan sekolah meningkat maka motivasi belajar akan meningkat juga.

Pengaruh variabel lain terhadap variabel terikat.

$$
\begin{aligned}
\rho_{X 2 \varepsilon 1} & =\sqrt{1-R^{2} x_{3} x_{1}} x_{2} X 4 \\
& =\sqrt{1-0,259} \\
& =0,741
\end{aligned}
$$

Koefisien tersebut memberikan makna kslau dampak variabel lain kepada motivasi belajar sebesar 25 , $9 \%$. 
Tabel 3. Hasil Analisis Jalur Sub Struktur II

\begin{tabular}{lcccc}
\hline \multicolumn{1}{c}{ Variabel Bebas } & $\begin{array}{c}\text { Koefisien } \\
\text { Jalur }\end{array}$ & $\mathrm{T}$ & Sig & Ket \\
\hline Keterampilan mengajar guru (X1) & 0,198 & 4,932 & 0,000 & Signifikan \\
Kesempatan belajar (X2) & 0,456 & 4,519 & 0,000 & Signifikan \\
Perhatian orang tua (X3) & 0,139 & 2,132 & 0,037 & Signifikan \\
Lingkungan sekolah (X4) & $-0,377$ & $-5,490$ & 0,000 & Signifikan \\
Motivasi belajar (X5) & 0,188 & 3,350 & 0,001 & Signifikan \\
\hline F hitung : 21,825 & & & & \\
F sig : 0,000 & & & & \\
R square : 0,613 & & & & \\
\hline Sumber: Olahan Data Primer (Peneliti) SPSS, 2020 & & &
\end{tabular}

Berdasarkan analisis pengaruh variabel keterampilan guru mengajar $\left(\mathrm{X}_{1}\right)$ terhadap variabel efektivitas belajar (Y) menunjukkan koefisien jalur $\rho_{Y X 1}=0,198$. Nilai $t_{\text {hitung }}=4,932$ dengan tingkat $\mathrm{t}_{\text {Tabel }}(1,993)$. Menurut analisis data diketahui bahwa ketarampilan mengajar guru berdampak positif dan signifikan kepada keefektifan pembelajaran. Ini memberikan gambaran kalau keterampilan mengajar guru meningkat maka efektivitas belajar akan meningkat juga.

Pengaruh variabel fasilitas mengajar $\left(\mathrm{X}_{2}\right)$ terhadap variabel efektivitas belajar (Y) menunjukkan koefisien jalur $\rho_{Y X 2}=0,456$. Nilai $\mathrm{t}_{\text {hitung }}=4,519$ dengan tingkat $\mathrm{t}_{\text {Tabel }}$ $(1,993)$. Berdasarkan analisis data dapat diketahui kalau fasilitas belajar memercikkan baik dan signifikan kepada keefektifan pembelajaran. Berikut memberikan gambaran bahwa apabila fasilitas mengajar meningkat maka efektivitas belajar akan meningkat juga.

Pengaruh variabel perhatian orangtua $\left(\mathrm{X}_{3}\right)$ kepada efektivitas belajar (Y) bahwa koefisien jalur $\rho_{Y X 3}$ $=0,139$. Nilai $t_{\text {hitung }}=2,132$ dengan taraf $\mathrm{t}_{\text {Tabel }}(1,993)$. Menurut analisis data tersebut melihatkan kalau perhatian orangtua berdampak positif dan signifikan kepada efektivitas belajar. Ini memberikan gambaran kalau perhatian orangtua naik maka efektivitas belajar juga akan naik pula.

Pengaruh variabel lingkungan sekolah $\left(\mathrm{X}_{4}\right)$ terhadap variabel 
efektivitas belajar (Y) menunjukkan koefisien jalur $\rho_{Y X 4}=-0,337$. Nilai $t_{\text {hitung }}=-5,490$ dengan tingkat $t_{\text {Tabel }}$ $(1,993)$. Menurut analisis data terlihat bahwa lingkungan sekolah berpengaruh negatif signifikan terhadap keefektifan belajarnya. Ini memberikan gambaran bahwa apabila lingkungan sekolah menurun maka efektivitas belajar akan menurun juga.

Pengaruh motivasi belajar $\left(\mathrm{X}_{5}\right)$ terhadap keefektifan belajar (Y) bahwa koefisien jalur $\rho_{Y X 5}=0,188$. Dengan $t_{\text {hitung }}=3,350$ dengan tingkat $t_{\text {Tabel }}$ (1,993). Berdasarkan analisis data tersebut melihatkan kalau motivasi belajar berdampak positif dan signifikan kepada efektivitas belajar. Ini mengambarkan bahwa motivasinya naik dengan demikian keefektifan belajarnya ikut naik pila.

Pengaruh variabel lain terhadap variabel terikat.

$$
\begin{aligned}
\rho_{X 2 \varepsilon 1} & =\sqrt{1-R^{2} y x_{1}} x_{2} x_{3} x_{3} \\
& =\sqrt{1-0,613} \\
& =0,387
\end{aligned}
$$

Koefisien tersebut memberikan gambaran kalau dampak variabel lain kepada efektivitas belajar siswa yaitu $61,3 \%$. Ini berarti bahwa selain perbedaan persepsi siswa tentang kemampuan guru mengajar di lingkungan pembelajran, perhatian orangtua, lingkungan sekolah, dan motivasi belajar, banyak faktor lain yang dapat mempengaruhi hal tersebut.

Hasil Uji hipotesis yang digunakan dalam penelitian ini terdiri dari dua macam yaitu uji t ( parsial). Adapun hasil iji hipotesis tersebut adalah sebagai berikut.

Pada variabel keterampilan guru mengajar diperoleh nilai koefisien jalur yaitu 0,198. Nilai t hitung 4,932 > t tabel $(1,993)$ yang artinya HO di buang dan Ha di terima. Sehingga dapat dikatakan terdapat pengaruh antara keterampilan guru di kelas kepada keefektifan belajar. Berdasarkan penelitian sebelumnya Novitasari. Dkk, (2017), melalui pemgaruh keterampilan guru mengajar, perhatian orang tua dan medi pembelajaran terhadap 
keefektifan belajar siswa pada mata pelajaran IPS VIII di SMP 04 Batang Anai, keterampilan mengajar guru berpengaruh terhadap keefektifan belajar siswa.

Di variabel fasilitas belajar diperoleh koefisien jalur 0,456. Koefisien ini signifikan sebab t hitung $4,519>\mathrm{t}$ tabel $(1,993)$ yang berarti H0 dibuang dan diambil. Demikian dapat dikatakan kalau terdapat pengaruh terhadap keefektifan belajar peserta didik antar lembaga pembelajaran. Menurut Syah (2011:154), fasilitas belajar adalah merupakan faktor yang dipandang turut menentukan tingkat keberhasilan belajar siswa.

Di variabel perhatian orang tua diperoleh koefisien jalur 0,139. Koefisien ini signifikan sebab t hitung 2,132> t hitung 2,993) yang berarti H0 ditolak dan $\mathrm{Ha}$ diterima. Sehingga dapat dikatakan terdapat pengaruh antara perhatian orang tua dengan keefektifan belajar siswa. Menurut Dalyono (2010:59) adalah banyak sedikitnya perhatian serta bimbingan dari orangtua, tinggi rendahnya pendapatan orangtua, rukun atau tidaknya kedua orang tua, akrab atau tidaknya, hubungan orang tua dengan anak-anak, tenang atau tidaknya situasi di rumahnya, semua itu turut mempengaruhi pencapaian hasil belajar anak.

Di variabel lingkungan sekolah diraih poin koefisien jalur -0,377. Poin koefisien tersebut signifikan sebab poin $\mathrm{t}$ hitung $-5,490>\mathrm{t}$ tabel (1.993) yang artinya $\mathrm{H} 0$ dibuang sedangkan Ha diambil. Sehingga dapat dikatakan bahwa antara lingkungan sekolah terdapat pengaruh terhadap keefektifan belajar siswa. Menurut Ahmadi (2005:33), lingkungan sekolah baik itu iyalah tempat dimana bisa membuat siswa semangat dalam belajar, aman, dan nyaman serta tercapainya apa yang diharapkan.

Dalam variabel keterampilan guru diperoleh poin koefisien jalur adalah 0,161. Poin koefisien tersebut signifikan sebab poin t hitung 1,931> t tabel (1,993) yang artinya H0 dibuang sedangkan Ha diambil. Jadi dapat dikatakan bahwa terdapat pengaruh antara keterampilan guru terhadap motivasi belajar siswa. 
Menurut Anni (2006:43), kehadiran keterampilan mengajar yang baik dari pihak guru diharapkan dapat merangsang minat siswa pada pelajaran berikutnya.

Di variabel fasilitas belajar diperoleh poin koefisien jalur adalah 0,573. Poin koefisien berikut signifikan sebab t hitungnya $-2,804>t$ tabelnya $(1,993)$ yang artinya $\mathrm{H0}$ dibuang sedangkan Ha diambil. Dengan demikian dapat dikatakan terdapat pengaruh terhadap motivasi belajar siswa antar lembaga pembelajaran. Menurut Sani (2013:48) proses belajar mengajar akan berlangsung efektif jika didukung oleh institusi yang sesuai

Di perhatian orangtuo diraih koefisien jalurnya yaitu 0,361. Poin ini signifikan sebab t hitungnya 2,675> t tabel $(1,993)$ yang berarti H0 dibuang dan Ha diterima. Jadi dapat dikatakan terdapat pengaruh antara perhatian orangtua dengan motivasi belajar siswa. Sejalan dengan penelitian sebelumnya yang dilakukan oleh Sauddeinuk. dkk, (2017), tentang pengaruh kebiasaan belajar, perhatian orangtua, dan motivasi belajar terhadap hasil belajar siswa kelas $\mathrm{X}$ SMAN 1 Siberut Tengah Kepulauan Mentawai diraih hasil terdapat pengaruh perhatian orangtua terhadap motivasi belajar.

Di variabel lingkungan sekolah diperoleh koefisien jalurnya yaitu 0,293 . Niai ini signifikan sebab nilai $\mathrm{t}$ hitung 2,056>t tabel (1,993), maka Ho dibuang dan Ha diambil. Maka dapat disimpulakan bahwa lingkungan sekolah mempengaruhi motivasi belajar siswa. Peneliti sebelumnya yaitu Wahyu. R, (2013). Pengaruh Kesiapan Guru Mengajar dan Lingkungan Belajar Terhadap Efektivitas Pembelajaran di SMK Kristen 1 Surakarta.

Di variabel motivasi belajar diperoleh poin koefisien jalur iyalah 0,188. Poin koefisien tersebut signifikan sebab poin $\mathrm{t}$ hitung 3,350> $\mathrm{t}$ tabel $(1,993)$ yang berarti H0 dibuang dan Ha diambil. Ini bisa dikatakan kalau motivasi belajar terhadap keefektifan belajarnya. Berdasarkan Dimyati,. (2006;7), belajar adalah perbuatan serta prilaku murid yang 
lengkap, sebab itu belajar hanya dilakukan siswa itu sendiri, siswa merupakan penentuan terjadi atau tidaknya kegiatan pembelajaran, kegiatan pembelajaran karna siswa meraih sesuatu yang ada di lingkungan sekitar.

\section{KESIMPULAN}

Menurut hasil analisis data
yang dilakukan maka dapat
disimpulkan sebagai berikut:

Terdapat pengaruh antara variabel keterampilan guru mengajar terhadap efektivitias belajar siswa, ada pengaruh antara variabel fasilitas belajarnya. Adanya penagruh antar variabel perhatian orangtua kepada keefektifan belajarnya, terdapat pengaruh antara variabel lingkungan sekolah terhadap efektivitias belajar siswa.

Terdapat pengaruh antara variabel keterampilan guru terhadap motivasi belajar siswa, terdapat pengaruh antara variabel fasilitas belajar terhadap motivasi belajar siswa, adanya pengaruh antar variabel perhatian orang tua kepada motivasi belajarnya, adanya pengaruh antar variabel lingkungan sekolah kepada motivasi belajar, adanya pengaruh antar motivasi belajarnya kepada efektivitas belajar.

\section{DAFTAR PUSTAKA}

Ahmadi. (2005). Faktor-faktor Yang Mempengaruhi Interaksi Belajar Mengajar. Bandung : Pustaka Setia.

Anni. (2006). Psikologi Belajar. Semarang: Universitas Negeri Semarang.

Arikunto. (2004). Evaluasi Program Pendidikan. Jakarta: Bumi Aksara.

Arikunto. (2006). Prosedur Penelitian Suatu Pendekatan Praktek, Jakarta: PT. Rineka Cipta.

Dalyono. (2010). Psikologi Pendidikan. Jakarta: PT Rineka Cipta.

Dimyati. (2006). Belajar dan Pembelajaran. Jakarta: PT Rineka Cipta.

nashori. (2005). Psikologi Islam. Yogyakarta: Pustaka Pelajar.

Novitasari. (2017). Pengaruh Keterampilan Guru Dalam Mengajar, Perhatian Orang Tua Dan Media Pembelajaran Terhadap Efektivitas 
Pembelajaran Siswa Pada Mata Pelajaran Ips Kelas VIII DI SMPN 04 Batang Anai. Jurnal Ilmiah Mahasiswa. https://doi.org/ http://jim. stkippgri- sumbar.ac.id /jurnal/ download/5131

Sadirman. (2011). Interaksi dan Motivasi Belajar Mengajar. Jakarta: PT Raja Grafindo Persada.

Sani. (2013). Inovasi Pembelajaran. Jakarta: Bumi Aksara.

Sauddeinuk, A. S., Jolianis, \& Sumarni. (2017). Pengaruh Kebiasaan Belajar, Perhatian Orang Tua Dan Motivasi Belajar Terhadap Hasil Belajar Siswa Kelas X Sma N 1 Siberut Tengah Kabupaten Kepulauan Mentawai. 5(2), 134-142. https://doi.org/ http://dx.doi.org/10.22202/ economica.2017.5.2.485

ABSTRAK

Slameto. (2003). Belajar dan Faktorfaktor yang Mempengaruhinya. Jakarta: Rineka Cipta.

Syah. (2011). Psikologi Pendidikan. Bandung: Remaja Rosdakarya.

Tu'u. (2004). Psikologi Belajar. Jakarta: Grasindo.

Wahyud, R. (2013). Pengaruh Kesiapan Guru Mengajar Dan Lingkungan Belajar Terhadap Efektivitas Pembelajaran Di Smk Kristen 1 Surakarta. 2(2), 37-48. https://doi.org/jurnal.fkip.uns.ac.i d/index.php/ekonomi/article/view /2913.http://dx.doi.org/12.0231/.2 017. 2.235

Zain, \& D. (2013). Strategi Belajar Mengajar. Jakarta: Rineka Cipta. 